University of Nebraska - Lincoln

DigitalCommons@University of Nebraska - Lincoln

USDA National Wildlife Research Center - Staff Publications
U.S. Department of Agriculture: Animal and Plant Health Inspection Service

2010

\title{
Arthropods of a semi-natural grassland in an urban environment: the John F. Kennedy International Airport, New York
}

\author{
Lisa Kutschbach-Brohl \\ USDA-APHIS-WS, National Wildlife Research Center \\ Brian E. Washburn \\ USDA-APHIS-WS, National Wildlife Research Center, brian.e.washburn@aphis.usda.gov \\ Glen E. Bernhardt \\ USDA-APHIS-WS, National Wildlife Research Center \\ Richard B. Chipman \\ USDA-APHIS-WS \\ Laura C. Francoeur \\ Port Authority of New York and New Jersey, John F. Kennedy International Airport
}

Follow this and additional works at: https://digitalcommons.unl.edu/icwdm_usdanwrc

Part of the Life Sciences Commons

Kutschbach-Brohl, Lisa; Washburn, Brian E.; Bernhardt, Glen E.; Chipman, Richard B.; and Francoeur, Laura C., "Arthropods of a semi-natural grassland in an urban environment: the John F. Kennedy International Airport, New York" (2010). USDA National Wildlife Research Center - Staff Publications. 1897.

https://digitalcommons.unl.edu/icwdm_usdanwrc/1897

This Article is brought to you for free and open access by the U.S. Department of Agriculture: Animal and Plant Health Inspection Service at DigitalCommons@University of Nebraska - Lincoln. It has been accepted for inclusion in USDA National Wildlife Research Center - Staff Publications by an authorized administrator of DigitalCommons@University of Nebraska - Lincoln. 


\title{
Arthropods of a semi-natural grassland in an urban environment: the John F. Kennedy International Airport, New York
}

\author{
Lisa Kutschbach-Brohl • Brian E. Washburn • \\ Glen E. Bernhardt $\cdot$ Richard B. Chipman • \\ Laura C. Francoeur
}

Received: 16 July 2009/ Accepted: 7 January 2010/Published online: 23 January 2010

(C) Springer Science+Business Media B.V. 2010

This document is a U.S. government work and
is not subject to copyright in the United States.

\begin{abstract}
Semi-natural grassland habitat fragments, such as those found on airports, might be important for arthropod conservation and biodiversity in urban ecosystems. The objectives of this study were to: (1) describe the arthropod communities present within the grasslands on the John F. Kennedy International Airport and (2) assess spatial and temporal variation in those arthropod communities. We collected arthropods using a vacuum sampler during 2003 and using sweep-net collection methods during 2003 and 2004. During 2003, a total of 1,467 arthropods, representing 17 orders and 68 families were found in vacuum samples. A total of 3,784 arthropods, representing 12 orders and 94 families were collected in sweep-net samples during 2003. In 2004, a total of 3,281 arthropods, representing 12 orders and 85 families were collected in sweepnet samples. Hemiptera, Orthoptera, and Diptera were the most abundant taxa, accounting for 47,18 , and $14 \%$ of all arthropods captured, respectively. We found evidence of spatial and temporal variation in arthropod abundance, in particular as noted by fluctuations in Orthoptera: Acrididae and Hemiptera: Auchenorrhyncha. Hemipteran family diversity was also influenced by habitat type. Grassland habitats on airfields, although influenced by anthropogenic factors (e.g., mowing), have the potential to provide
\end{abstract}

L. Kutschbach-Brohl · B. E. Washburn $(\varangle)$ · G. E. Bernhardt USDA-APHIS-WS, National Wildlife Research Center, 6100 Columbus Avenue, Sandusky, OH 44870, USA

e-mail: brian.e.washburn@aphis.usda.gov

R. B. Chipman

USDA-APHIS-WS, 1930 Route 9, Castleton, NY 12033, USA

L. C. Francoeur

Port Authority of New York and New Jersey, John F. Kennedy International Airport, Building 145, Jamaica, NY 11430, USA abundant and diverse arthropod communities and might serve as a refugium for such species within urban ecosystems.

Keywords John F. Kennedy International Airport . Insects · Grassland · Sweep sample · Vacuum sample · Urban entomology

\section{Introduction}

Although urbanization is considered to be one of the primary causes of declines in arthropod populations around the world (Pyle et al. 1981; McIntyre 2000), little information is known about arthropod communities in urban areas (Frankie and Ehler 1978; Clark and Samways 1997; McIntyre 2000). Within highly urbanized areas, arthropods can be found in a variety of semi-natural and man-made habitats, including natural habitat fragments (Panzer et al. 1995; Blair and Launer 1997; Collinge et al. 2003; Dover et al. 2009), parks (Faeth and Kane 1978; Kadlec et al. 2008; Pöyry et al. 2009), residential and commercial lawns (Cockfield and Potter 1984; Rochefort et al. 2006; Joseph and Braman 2009), roadsides and railways (Eversham et al. 1996; Valtonen et al. 2007), golf courses (New 2005; Yasuda and Koike 2006; Yasuda et al. 2008), brownfield sites (Eyre et al. 2003; Kadas 2006), gardens (Gaston et al. 2005; Smith et al. 2006), and green roofs (Kadas 2006; Schrader and Böning 2006). Research examining the structure and composition of arthropod communities within urban habitats might provide insights into the effects of urbanization on arthropods and information needed to preserve or promote biodiversity in urban ecosystems (Zapparoli 1997; McIntyre 2000). 
Grassland habitats (e.g., hayfields, turfgrass areas) in the eastern United States are typically subjected to anthropogenic influences and dominated by introduced cool-season grasses (e.g., Lolium arundinaceum (Schreb.) S.J. Darbyshire [tall fescue]), Phleum pratense L. [timothy], coolseason forbs and legumes (e.g., Trifolium spp. L. [clovers]) and few native plants (Askins 1997; Norment 2002). Remnant semi-natural grasslands, in particular those serving as habitat fragments, are essential to the maintenance of diverse terrestrial arthropod communities within humandominated (e.g., agriculture, urbanized) landscapes (Panzer et al. 1995; Picker and Samways 1996; Tscharntke et al. 2002; Öckinger and Smith 2007). These semi-natural grassland habitats have the potential to support diverse and abundant populations of arthropods yet little is known of their distribution or ecology in northeastern North America (Goldstein 1997).

With increasing urbanization, airports often provide some of the largest areas of semi-natural grassland habitats available to flora and fauna (Caccamise et al. 1996; Mehrhoff 1997; Greller et al. 2000; Norment 2002) within urban and suburban areas. The extensive semi-natural grasslands of the John F. Kennedy International Airport (JFKIA) represent a fundamentally scarce habitat in the metropolitan New York City area and western Long Island (Buckley and McCarthy 1994; USFWS 1997; NYCDEP 2007). The objectives of this study were to: (1) describe the arthropod communities present within the grasslands of the John F. Kennedy International Airport and (2) to assess spatial and temporal variation in those arthropod communities.

\section{Methods}

Study area

This study was conducted on airfield grassland areas of the JFKIA $\left(40^{\circ} 38^{\prime} \mathrm{N}, 73^{\circ} 47^{\prime} \mathrm{W}\right)$; the airport is located at the southwestern end of Long Island in Jamaica, New York. The JFKIA airfield is 1995 ha in size and in addition to paved surfaces (e.g., aircraft runways and taxiways) is characterized by large areas of cool-season turfgrass, sparse weedy vegetation, and some small trees and shrubs (Barras et al. 2000). The airport is bordered by a protected saltwater bay (Jamaica Bay) to the south and heavily urbanized residential and commercial areas on the other three sides.

The area currently occupied by JFKIA was originally Spartina alterniflora L. (smooth cordgrass) marsh (USFWS 1997). The parent material for the soils present on the JFKIA airfield are primarily hydraulic fill and sandy dredge material from the adjacent Jamaica Bay and more recently construction fill and debris (NYCDEP 2007). Mean annual precipitation at the study area is $1,200 \mathrm{~mm}$ per year, with $43 \%$ typically falling as rain during growing season (USDA 2005). The average daily temperature during summer is $24^{\circ} \mathrm{C}$. The urban soils on the study area consisted of Inwood, Laguardiam and Ebbets series (coarse-loamy or fragmental, mixed, active, mesic Typic Udorthents) loamy fill, sandy dredge, and construction debris mixed with natural soil (USDA 2005).

We identified four grassland habitat areas on the JFKIA airfield that had the potential to be ecologically distinct (Fig. 1): 'Bay runway' (60 ha in size), 'K-extension' (35 ha), 'Between the 4s' (115 ha), and the 'Old meadow' (95 ha) habitat areas. The Bay runway habitat area was grasslands consisting mostly of large amounts (85-90\% cover) of Bromus japonicus Thunb. ex Murr. (Japanese brome) and Lespedeza spp. Michx. (lespedeza; 5-10\% cover). The K-extension habitat area was characterized by sparser vegetation, consisting primarily ( $45-50 \%$ cover) of grasses (e.g., B. japonicus) with forbs (20-25\% cover; e.g., Solidago sempervirens L. [seaside goldenrod]) and a few small woody plants ( $<5 \%$ cover; e.g., Rosa rugosa Thunb. [wrinkled rose]). The Between the $4 \mathrm{~s}$ habitat area was predominately cool-season turfgrasses (90-95\% cover), such as tall fescue. The Old meadow habitat area was comprised of sparse $(<20 \%$ cover $)$ native warm-season grasses (e.g., Andropogon virginicus L. [broomsedge], Panicum virgatum L. [switchgrass], Schizachyrium scoparium (Michx.) Nash [little bluestem]) interspersed with trees and shrubs (e.g., Betula populifolia Marsh. [gray birch], Alnus serrulata (Ait.) Willd. [alder], Rhus copallinum L. [shining sumac]). Except for the Old meadow habitat area, which was undisturbed, the grassland habitat areas on the JFKIA airfield were adjacent to runways and

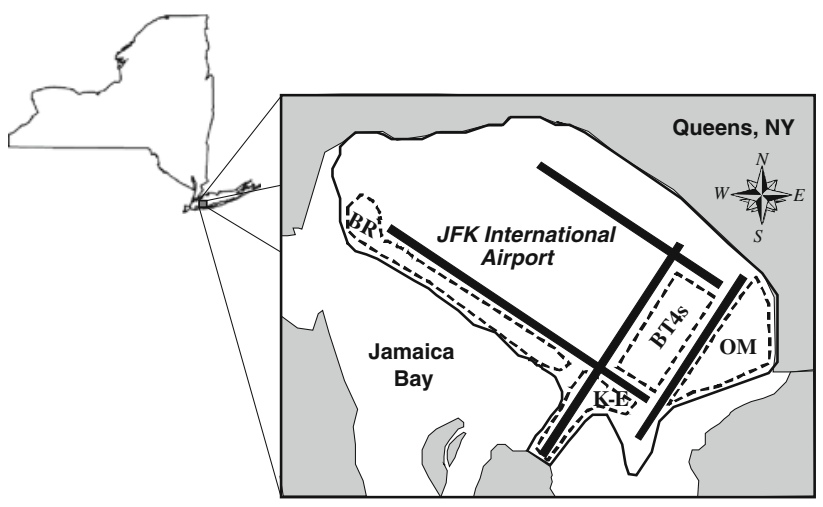

Fig. 1 Location of John F. Kennedy International Airport, Jamaica, $\mathrm{NY}$, and the four habitat areas on the airfield where arthropod samples were collected in 2003 and 2004. BR Bay runway habitat area; $K-E \mathrm{~K}$ Extension habitat area; BT4s Between the 4s habitat area; OM Old meadow habitat area 
taxiways and mowed to a height of $15 \mathrm{~cm}$ twice during the growing season each year.

\section{Vacuum sampling}

Arthropod communities in grassland habitats on the JFKIA airfield were sampled using a suction (vacuum) sampling device that was constructed from a Poulan PRO $^{\circledR} 25 \mathrm{cc}$ leaf-blower (Electrolux Home Products, Augusta, GA). This device was constructed by incorporating design elements from terrestrial arthropod suction sampling equipment described by other researchers (Stewart and Wright 1995; Harper and Guynn 1998). Vacuum samples were collected weekly between 1300 and $1800 \mathrm{~h}$ from May to September in 2003 at 30 locations on the JFKIA airfield (Fig. 1). In 2003, samples were collected within the Bay runway ( $n=11$ collection points), the K-extension $(n=6)$, the Between the $4 \mathrm{~s}(n=5)$, and the Old meadow $(n=8)$ habitat areas (Fig. 1). At each sample collection location, a sample plot was randomly chosen within a $20 \mathrm{~m}$ radius of the sample collection point marker. A plastic tub with the bottom removed (providing a sample area of $0.34 \mathrm{~m}^{2}$ ) was placed onto the ground with the lid in place. The lid was lifted and the vacuum sampler nozzle was inserted into the tub and moved in a methodical manner back and forth over the soil and vegetation for $30 \mathrm{~s}$. The contents of the sample collection net were placed into a plastic freezer bag, placed on ice in the field, and frozen at $-20^{\circ} \mathrm{C}$ within $4 \mathrm{~h}$ of collection.

\section{Sweep-net sampling}

Sweep-net samples were collected concurrently with vacuum samples (in regard to time and sample collection point) on a weekly basis between 1300 and $1800 \mathrm{~h}$ at a total of 30 invertebrate sample collection points (July to September) in 2003 using a standard sweep-net sampling method (Fuhlendorf et al. 2002; Nickel and Hildebrandt 2003; Gardiner and Hill 2006). From a randomly chosen starting point (within $20 \mathrm{~m}$ of the sample collection point marker), we walked for $\sim 8.3 \mathrm{~m}$, sweeping a $37.6-\mathrm{cm}$ diameter muslin net (Geb-Net Enterprises, Berlin Heights, $\mathrm{OH}$ ) back and forth in $180^{\circ}$ arcs through the vegetation (approximately $5 \mathrm{~cm}$ from the ground); each sweep-net sample in 2003 provided an estimated sampling area of $14.1 \mathrm{~m}^{2}$. The contents of each sweep-net sample was placed into a plastic freezer bag, placed on ice in the field, and frozen at $-20^{\circ} \mathrm{C}$ within $4 \mathrm{~h}$ of collection.

Sweep-net samples were collected weekly between 1300 and $1800 \mathrm{~h}$ at a total of 20 collection points (May to September) in 2004. Sweep-net samples were collected at 10, 5 , and 5 collection points within the Bay runway, K-extension, Between the $4 \mathrm{~s}$ habitat areas (Fig. 1), respectively. From a randomly chosen starting point (within $20 \mathrm{~m}$ of the sample collection point marker), we walked for $25 \mathrm{~m}$, sweeping a 37.6-cm wide "D-shaped" muslin net (Geb-Net Enterprises, Berlin Heights, $\mathrm{OH}$ ) through the vegetation (approximately $5 \mathrm{~cm}$ from the ground) and parallel to the direction of travel; each sweep-net sample in 2004 provided an estimated sampling area of $10.3 \mathrm{~m}^{2}$. The contents of each sweep-net sample were placed into a plastic freezer bag, placed on ice in the field, and frozen at $-20^{\circ} \mathrm{C}$ within $4 \mathrm{~h}$ of collection.

All insect samples were kept frozen and transported to the USDA-APHIS-WS National Wildlife Research Center in Sandusky, Ohio. With the aid of dissecting microscopes, all samples were individually sorted and all arthropods found within each sample were identified to the lowest practical taxonomic level and counted. Arthropod taxonomic nomenclature followed Triplehorn and Johnson (2005). After identification, we classified insect taxonomic families into functional feeding groups based on consensus information primarily from Borror and White (1970), Dillon and Dillon (1972), McAlpine et al. (1981), McAlpine et al. (1987), and Triplehorn and Johnson (2005).

\section{Data analyses}

To standardize arthropod capture rates between the two sampling methods and among the four habitats, all arthropod density data (vacuum samples) and relative abundance data (sweep-net samples) were compared using the mean number of arthropods collected per sample. The arthropod density and relative abundance data were not normally distributed and could not be transformed satisfactorily. Therefore, we compared insect abundance among habitat areas using Kruskal-Wallis tests (test statistic $H$ ) for each sampling method (and year) and considered differences significant at $P \leq 0.05$ (Zar 1996).

We calculated richness of Coleoptera and Orthoptera families within each of the four habitat types by sampling method/year. Comparison of Hemipteran family diversity was done using rarefied estimates (Gotelli and Entsminger 2001; Magurran 2004) of family richness using EcoSim software (Gotelli and Entsminger 2005). Using within-taxa richness (e.g., familial richness) has been shown to be a viable surrogate for species richness (Magurran 2004).

\section{Results}

Arthropod communities

In 2 years of sampling (using two methods), a total of 8,532 arthropods were collected on the JFKIA airfield. Among all arthropods collected during the study, 5 taxonomic classes, 18 orders, and 125 families were represented. In 2003, 
1,467 arthropods (1,301 insects and 166 non-insect arthropods), representing 17 taxonomic orders and 68 families were collected and identified in the vacuum samples. Sweep-net samples in 2003 contained 3,784 arthropods (3,732 insects and 52 non-insect arthropods), representing 12 orders and 94 families, whereas 3,281 arthropods $(3,197$ insects and 84 non-insect arthropods), representing 12 orders and 85 families, were found and identified in the sweep-net samples collected in 2004.

\section{Non-insect arthropods}

Although the vast majority (97\%) of the arthropods collected at JFKIA were insects (Hexapoda), non-insect arthropods were collected during both the vacuum and sweep-net sampling efforts. Spiders (Arachnida: Araneae) were the most abundant of the non-insect arthropods, comprising 9, 1, and $3 \%$ of the arthropods collected during the vacuum sampling, the sweep-net sampling in 2003, and the sweep-net sampling in 2004, respectively. We found mites (Arachnida: Acari) in both vacuum and sweep-net samples, whereas Malacostraca (Isopoda), Chilopoda, and Diplopoda were present exclusively in the vacuum samples.

\section{Insect taxa}

Hemiptera, Orthoptera, and Diptera were the most abundant insect taxa, accounting for 47,18 , and $14 \%$ of all arthropods captured in the grassland areas of JFKIA. The next most abundant taxa were Hymenoptera (7\%), Coleoptera (6\%), and Lepidoptera (4\%). All remaining taxa accounted for $<1 \%$ of all arthropods collected during this study.

Hemiptera, including representative families from the Heteroptera, Auchenorrhyncha, and Sternorryncha suborders, were the most abundant taxa (a total of 4,035 individuals from 19 families were collected) occurring in both vacuum and sweep-net samples. Auchenorrhyncha and Heteroptera accounted for 29 and $14 \%$ of all arthropods collected, respectively. The most frequently occurring Hemipteran families in the vacuum samples were Cicadellidae (leafhoppers) and Miridae (plant bugs). Cicadellidae, Miridae, Delphacidae (plant hoppers), Aphididae (aphids), and Cercopidae (froghoppers) were the most frequently collected Hemipteran families in the sweep-net samples.

Orthopterans were the second most abundant arthropod taxa collected during this study. Acrididae (short-horned grasshoppers) comprised $95 \%$ of the Orthoptera collected in the grassland habitats, with representatives from the Melanoplinae, Oedipodinae, and Acridinae (only 2 individuals) subfamilies. Gryllidae (true crickets) were also present, with individuals from the Oecanthinae, Gryllinae, and Nemobiinae (only 3 individuals) subfamilies. We also found 2 Tettigonidae (katydids). The majority of Orthopterans collected were early instars, which made identification to lower taxonomic levels difficult.

The most abundant Dipteran families collected during vacuum and sweep-net sampling in the grasslands at JFKIA were Chloropidae (grass flies), Drosophilidae (pumace flies), Dolichopodidae (long-legged flies), and Syrphidae (flower flies). We were unable to identify approximately one-half (48\%) of the Dipterans collected to the taxonomic level of family, due to damage to specimens presumably occurring during the collection process.

Coleoptera and Hymenoptera were present in both vacuum and sweep-net samples, although not unexpectedly the overall composition of taxa varied between the two sampling methods. Carabidae (ground beetles) and Curculionidae (snout beetles and weevils) were the most frequently observed beetles in the vacuum samples, whereas sweep-net samples were comprised primarily of Phalacridae (shining flower beetles), Coccinellidae (ladybird beetles), and Curculionidae.

Although Formicidae (ants) comprised 92\% of the Hymenoptera collected by vacuum sampling, this family comprised only $23 \%$ of the Hymenoptera collected by sweep-netting. Geometridae (geometrid moths) and Noctuidae (owlet moths) were the most abundant Lepidoptera, although most Lepidopteran specimens from both sweep and vacuum samples were in immature stages (only $31 \%$ were successfully identified to the family level).

The major functional feeding groups among terrestrial arthropods were represented by many arthropod families collected from the grassland habitats of the JFKIA airfield during this study. Among the 125 taxonomic families we collected, 44 were herbivores, 31 were predators, 27 were detritivores, 9 were pollinators, and 12 were parasitoid. The remaining two families (Chironomidae and Formicidae) could not be categorized into one functional feeding group.

Spatial variability of arthropod abundance and diversity

With the exception of Hymenoptera, we found no differences in the density of various arthropod taxa within the four distinct grassland habitats in vacuum samples from 2003 (Table 1). The average number of Hymenoptera captured in the Bay runway habitat area was higher ( $H=15.02, P=0.002$ ) than Hymenoptera collected in the Between the $4 \mathrm{~s}$ habitat area. Orthopteran (1-2) and Coleopteran family richness (6-11) was similar among habitat areas, whereas Hemiptera family diversity was highest within the Between the $4 \mathrm{~s}$ habitat area and lowest in the Bay runway area (Fig. 2). 
Table 1 Average $( \pm \mathrm{SE})$ no. of arthropods per vacuum sample $\left(0.34 \mathrm{~m}^{2}\right)$ of selected taxonomic orders and Hemiptera suborders in four habitat areas of the airfield at John F. Kennedy International Airport, Jamaica, NY, May 2003 through September 2003

\begin{tabular}{|c|c|c|c|c|}
\hline \multirow[t]{2}{*}{ Order } & \multicolumn{4}{|c|}{ No. of arthropods per vacuum sample $( \pm \mathrm{SE})$} \\
\hline & Bay runway & K-extension & Between the $4 \mathrm{~s}$ & Old meadow \\
\hline Coleoptera & $0.6 \pm 0.08 \mathrm{a}$ & $0.6 \pm 0.08 \mathrm{a}$ & $0.4 \pm 0.08 \mathrm{a}$ & $0.6 \pm 0.14 \mathrm{a}$ \\
\hline Diptera & $0.3 \pm 0.06 \mathrm{a}$ & $0.3 \pm 0.06 \mathrm{a}$ & $0.2 \pm 0.09 \mathrm{a}$ & $0.2 \pm 0.07 \mathrm{a}$ \\
\hline Hemiptera & $0.8 \pm 0.11 \mathrm{a}$ & $1.1 \pm 0.22 \mathrm{a}$ & $0.8 \pm 0.18 \mathrm{a}$ & $0.1 \pm 0.17 \mathrm{a}$ \\
\hline (Heteroptera) & $0.3 \pm 0.06 \mathrm{a}$ & $0.5 \pm 0.13 \mathrm{a}$ & $0.3 \pm 0.11 \mathrm{a}$ & $0.2 \pm 0.06 \mathrm{a}$ \\
\hline (Auchenorrhyncha) & $0.3 \pm 0.06 \mathrm{a}$ & $0.5 \pm 0.14 \mathrm{a}$ & $0.3 \pm 0.11 \mathrm{a}$ & $0.6 \pm 0.12 \mathrm{a}$ \\
\hline (Sternorrhyncha) & $0.1 \pm 0.05 \mathrm{a}$ & $0.1 \pm 0.04 \mathrm{a}$ & $0.1 \pm 0.03 a$ & $0.1 \pm 0.03 \mathrm{a}$ \\
\hline Hymenoptera & $1.1 \pm 0.22 \mathrm{a}$ & $0.8 \pm 0.16 \mathrm{ab}$ & $0.3 \pm 0.16 b$ & $0.6 \pm 0.13 \mathrm{ab}$ \\
\hline Lepidoptera & $0.1 \pm 0.02 \mathrm{a}$ & $0.2 \pm 0.06 \mathrm{a}$ & $0.2 \pm 0.02 \mathrm{a}$ & $0.2 \pm 0.04 \mathrm{a}$ \\
\hline Orthoptera & $0.1 \pm 0.02 \mathrm{a}$ & $0.1 \pm 0.05 \mathrm{a}$ & $0.1 \pm 0.04 \mathrm{a}$ & $0.2 \pm 0.04 a$ \\
\hline Minor $^{\mathrm{a}}$ & $0.1 \pm 0.03 \mathrm{a}$ & $0.1 \pm 0.02 \mathrm{a}$ & $0.1 \pm 0.03 \mathrm{a}$ & $0.1 \pm 0.03 \mathrm{a}$ \\
\hline Non-insect ${ }^{\mathrm{b}}$ & $0.3 \pm 0.07 \mathrm{a}$ & $0.4 \pm 0.08 \mathrm{a}$ & $0.2 \pm 0.06 b$ & $0.5 \pm 0.11 \mathrm{a}$ \\
\hline All orders combined & $3.4 \pm 0.35 \mathrm{a}$ & $3.5 \pm 0.39 \mathrm{a}$ & $2.3 \pm 0.35 \mathrm{a}$ & $3.2 \pm 0.39 \mathrm{a}$ \\
\hline
\end{tabular}

Means within the same row with the same letter are not different $(P>0.05)$ according to a Kruskal-Wallis test

a Minor insect orders included Collembola, Dermaptera, Isoptera, Mantodea, Neuroptera, Odonata, and Thysanoptera

b Non-insect arthropods included Arachnida (Acari and Araneae), Malacostraca (Isopoda), Chilopoda, and Diplopoda

In 2003, the average number of arthropods collected in sweep-net samples in the K-extension habitat area was two to three times higher $(H=13.57, P=0.004)$ than the average number of arthropods in the other three habitat areas. This difference among habitat areas was due to higher abundances of Hemiptera (specifically Auchenorrhyncha), Orthoptera (Acrididae), Diptera, and Hymenoptera in the K-extension habitat area relative to the other grasslands (Table 2). Although the Old meadow habitat area had the highest relative abundance of noninsect arthropods collected by sweep-netting, this area also had the lowest abundance of Hemiptera (especially Auchenorrhyncha) and Orthoptera (Table 2). Similar to the vacuum samples, Orthopteran (1-3) and Coleopteran family richness (6-11) was not different among habitat areas, whereas family richness of Hemiptera was highest within the Between the 4s habitat area (Fig. 2).

In contrast to the previous year (2003), the average number of arthropods collected by sweep-net during 2004 in the K-extension habitat area was lower $(H=18.31$, $P<0.001)$ than the average number of arthropods collected in the Bay runway and Between the $4 \mathrm{~s}$ habitat areas. The relative abundance of arthropod taxa were similar among the grassland habitat areas sampled, with two notable exceptions (Table 3). Orthoptera (mostly Acrididae: Melanoplinae: Melanoplus) were four times more abundant $(H=70.69, P<0.001)$ in the Between the 4 s habitat area than in the Bay runway and K-extension habitat areas. Hemiptera, including Heteroptera and Auchenorrhyncha, were more abundant $(H=18.44, P<0.0001)$ in the Bay runway habitat area than in the K-extension and Between the $4 \mathrm{~s}$ grassland habitats (Table 3). Family richness of Orthoptera (2-3) and Coleopteran family richness (6-11) did not vary among the habitat areas. The Bay runway habitat area had much lower Hemipteran family richness than the other 2 habitat areas (Fig. 2).

Temporal patterns of arthropod abundance

Arthropod abundance, as assessed by vacuum sampling, did not vary among the summer months (Fig. 3). The average density of arthropods per $0.34 \mathrm{~m}^{2}$ was similar during May to September in the Bay runway $(H=7.01$, $P=0.14)$, K-extension $(H=3.55, P=0.47)$, Between the $4 \mathrm{~s}(H=0.77, P=0.86)$, and Old meadow $(H=7.20$, $P=0.13$ ) habitat areas.

Sweep-net sampling in 2003 showed that the relative abundance of arthropods increased during mid to late summer in all four habitat areas (Fig. 4). The average number of arthropods collected per sample in September was higher than the average number collected per sample in July in the Bay runway $(H=16.65, P<0.001)$, K-extension $(H=15.03, P<0.001)$, Between the $4 \mathrm{~s}$ $(H=15.30, P<0.001)$, and Old meadow $(H=11.05$, $P=0.004)$ habitat areas. The abundance of arthropods increased three fold from August to September of 2003 in the K-extension grassland area (Fig. 3); this increase was almost entirely due to an increase in Auchenorrhyncha populations.

In contrast to 2003, patterns of arthropod abundance varied among the grassland habitat areas during summer months in 2004 (Fig. 5). The average number of arthropods 

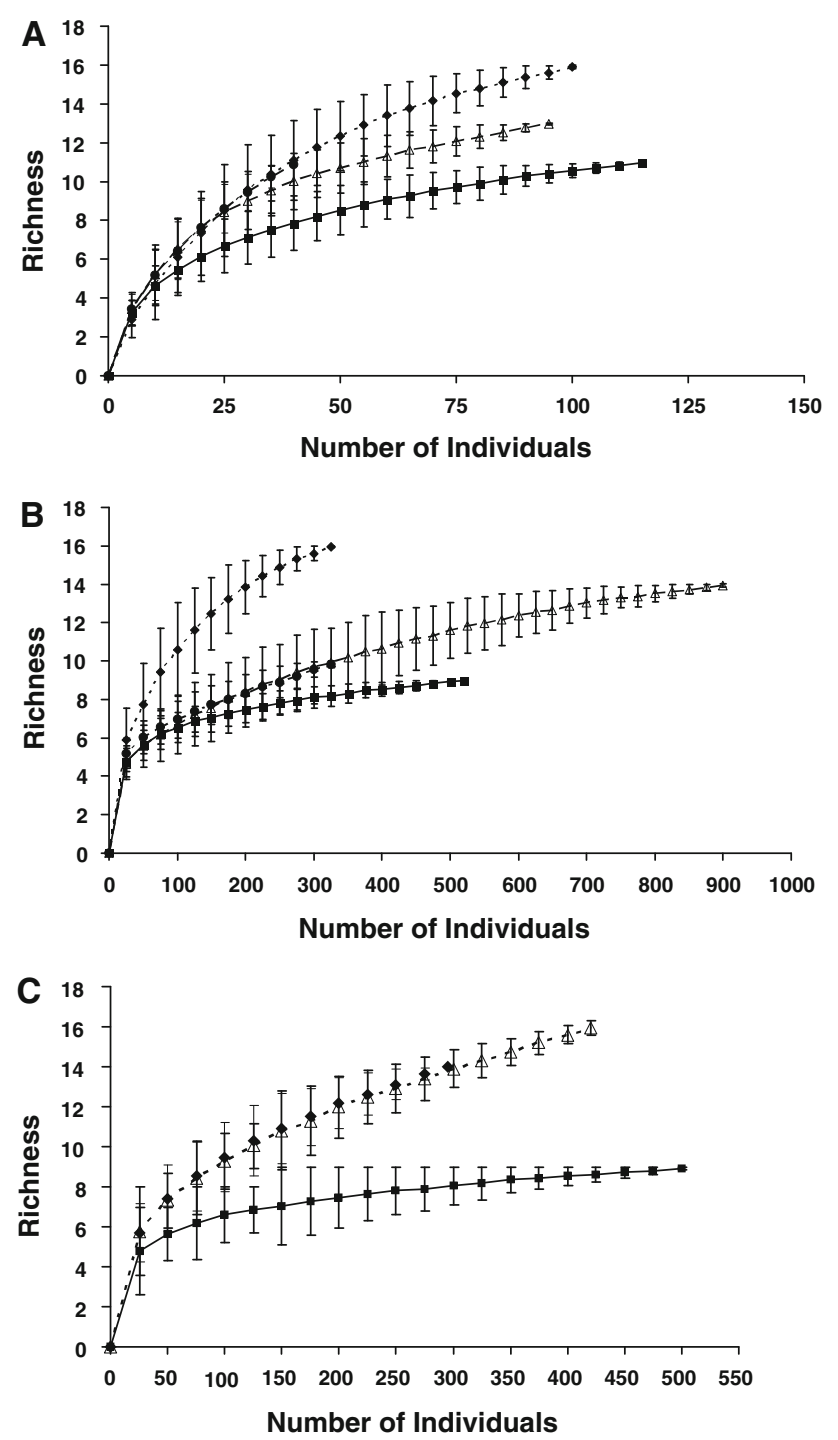

Fig. 2 Rarefaction curves for Hemiptera families collected in four grassland habitats on the airfield of the John F. Kennedy International Airport. The expected number of families is plotted against subsamples (number of individuals) and error bars are $\pm 95 \%$ Confidence Intervals. The Bay runway area is represented by (solid) squares, the K-Extension area by (open) triangles, the Between the $4 \mathrm{~s}$ area by (solid) diamonds, and the Old meadow area by (solid) circles. a Vacuum samples in 2003, b Sweep-nets in 2003, and c sweep-net samples in 2004

per sweep-net sample did not vary $(H=2.58, P=0.63)$ among months in the Bay runway habitat area, remained constant except for a significant increase from June to July $(H=10.79, P=0.03)$ in the $\mathrm{K}$-extension habitat area, and decreased $(H=15.30, P=0.006)$ from May to September in the Between the $4 \mathrm{~s}$ habitat area. Variation in arthropod populations in the Bay runway habitat area in 2004 was due primarily to changes in Auchenorrhyncha abundance. Declines in Orthoptera: Acrididae abundance, the most abundant taxa in the Between the 4s habitat area in 2004, were reflected in the overall decline in arthropods from May to September.

\section{Discussion}

Arthropod communities

The dominance of Hemiptera, Orthoptera, and Diptera in the arthropod samples collected from the grassland habitats on the JFKIA airfield is consistent with other studies examining terrestrial arthropod communities in native and agricultural grasslands (Tscharntke and Greiler 1995; Jonas et al. 2002; McIntyre and Thompson 2003). Most of the insect families collected in these semi-natural grassland habitats are closely associated with grasses and decaying vegetation. The Hemipteran families collected in the grassland habitats of the JFKIA airfield are primarily phytophagous and the most abundant Hemipteran families, Cicadellidae and Delphacidae, are closely associated with grasses and sedges (Morris 2000; Nickel and Hildebrant 2003). The Dipteran families inhabiting the grassland habitats at JFKIA are representative of flies normally associated with grassland areas (Chloropidae), along margins of water in soil and vegetation (Dolichopodidae), or with flowering plants (Syrphidae) (Borror and White 1970; McAlpine et al. 1981; McAlpine et al. 1987). Drosophilidae (pomace flies) are generally found near decaying fruits or vegetation (Triplehorn and Johnson 2005) and this family contains numerous species affiliated with urban areas (Frankie and Ehler 1978).

Terrestrial arthropods representing all of the major functional feeding groups (including herbivores, predators, detritivores, pollinators, and parasitoids) were found in the grassland habitats of the JFKIA airfield. The most abundant Coleoptera families collected in this study reflect this and were distributed among the arthropod functional feeding groups. Curculionidae are primarily herbivorous (Triplehorn and Johnson 2005), whereas Carabidae (ground beetles) are very active, predacious beetles (Dillon and Dillon 1972; Törmälä 1982). Coccinellidae feed primarily on aphids (Borror and White 1970). Phalacridae are pollen feeders commonly found on the flowers of Solidago spp. L. (goldenrod) and other composites (Asteraceae) (Triplehorn and Johnson 2005).

Spatial variability of arthropod abundance and diversity

The four grassland habitat types examined in this study represent the major components of the urban semi-natural grassland ecosystem that comprises the JFKIA airfield. These grassland habitats are relatively similar, although they have some differences in plant community composition 
Table 2 Average $( \pm$ SE) no. of arthropods per sweep-net sample of selected taxonomic orders and Hemiptera suborders in four habitat areas of the airfield at John F. Kennedy International Airport, Jamaica, NY, June 2003 through September 2003

\begin{tabular}{|c|c|c|c|c|}
\hline \multirow[t]{2}{*}{ Order } & \multicolumn{4}{|c|}{ No. of arthropods per sweep-net sample $( \pm \mathrm{SE})$} \\
\hline & Bay runway & K-extension & Between the $4 \mathrm{~s}$ & Old meadow \\
\hline Coleoptera & $0.5 \pm 0.12 \mathrm{a}$ & $0.9 \pm 0.22 \mathrm{a}$ & $0.2 \pm 0.08 \mathrm{a}$ & $1.0 \pm 0.28 \mathrm{a}$ \\
\hline Diptera & $2.4 \pm 0.35 \mathrm{a}$ & $4.9 \pm 0.71 b$ & $3.6 \pm 0.09 \mathrm{ab}$ & $2.0 \pm 0.32 \mathrm{a}$ \\
\hline Hemiptera & $8.5 \pm 0.95 a$ & $19.7 \pm 5.94 a$ & $9.6 \pm 1.63 \mathrm{a}$ & $6.0 \pm 1.03 b$ \\
\hline (Heteroptera) & $3.0 \pm 0.46 a$ & $6.1 \pm 3.86 a$ & $2.3 \pm 0.59 a$ & $1.9 \pm 0.46 \mathrm{a}$ \\
\hline (Auchenorrhyncha) & $5.2 \pm 0.77 \mathrm{a}$ & $13.3 \pm 4.61 \mathrm{a}$ & $7.4 \pm 1.40 \mathrm{a}$ & $3.9 \pm 0.88 \mathrm{~b}$ \\
\hline (Sternorrhyncha) & $0.2 \pm 0.06 a$ & $0.2 \pm 0.11 \mathrm{a}$ & $0.0 \pm 0.00 \mathrm{a}$ & $0.1 \pm 0.07 \mathrm{a}$ \\
\hline Hymenoptera & $0.5 \pm 0.09 \mathrm{a}$ & $0.7 \pm 0.15 b$ & $0.3 \pm 0.16 \mathrm{a}$ & $0.4 \pm 0.14 \mathrm{a}$ \\
\hline Lepidoptera & $0.5 \pm 0.10 \mathrm{a}$ & $0.6 \pm 0.16 \mathrm{a}$ & $0.6 \pm 0.02 \mathrm{a}$ & $0.7 \pm 0.23 \mathrm{a}$ \\
\hline Orthoptera & $0.6 \pm 0.09 \mathrm{ab}$ & $3.5 \pm 0.73 c$ & $1.5 \pm 0.04 \mathrm{bc}$ & $0.4 \pm 0.14 \mathrm{a}$ \\
\hline Minor $^{\mathrm{a}}$ & $0.1 \pm 0.04 \mathrm{a}$ & $0.1 \pm 0.05 \mathrm{a}$ & $0.0 \pm 0.00 \mathrm{a}$ & $0.1 \pm 0.03 \mathrm{a}$ \\
\hline Non-insect ${ }^{\mathrm{b}}$ & $0.1 \pm 0.04 \mathrm{a}$ & $0.3 \pm 0.10 \mathrm{ab}$ & $0.1 \pm 0.04 \mathrm{a}$ & $0.5 \pm 0.16 \mathrm{~b}$ \\
\hline All orders combined & $13.2 \pm 1.33 \mathrm{a}$ & $30.7 \pm 6.38 b$ & $15.9 \pm 2.35 \mathrm{ab}$ & $11.0 \pm 1.47 \mathrm{a}$ \\
\hline
\end{tabular}

Means within the same row with the same letter are not different $(P>0.05)$ according to a Kruskal-Wallis test

${ }^{a}$ Minor insect orders included Mantodea, Neuroptera, Psocoptera, and Thysanoptera

b Non-insect arthropod orders included Acari and Araneae

Table 3 Average $( \pm \mathrm{SE})$ no. of arthropods per sweep-net sample of selected taxonomic orders and Hemiptera suborders in three habitat areas of the airfield at John F. Kennedy International Airport, Jamaica, NY, May 2004 through September 2004

\begin{tabular}{|c|c|c|c|}
\hline \multirow[t]{2}{*}{ Order } & \multicolumn{3}{|c|}{ No. of arthropods per sweep-net sample $( \pm \mathrm{SE})$} \\
\hline & Bay runway & K-extension & Between the $4 \mathrm{~s}$ \\
\hline Coleoptera & $0.4 \pm 0.14 \mathrm{a}$ & $0.4 \pm 0.11 \mathrm{a}$ & $0.4 \pm 0.09 \mathrm{a}$ \\
\hline Diptera & $1.5 \pm 0.26 \mathrm{a}$ & $1.1 \pm 0.18 \mathrm{a}$ & $1.5 \pm 0.18 \mathrm{a}$ \\
\hline Hemiptera & $10.0 \pm 2.52 \mathrm{a}$ & $3.9 \pm 0.60 \mathrm{~b}$ & $3.4 \pm 0.52 b$ \\
\hline (Heteroptera) & $2.2 \pm 0.94 \mathrm{a}$ & $1.4 \pm 0.24 \mathrm{ab}$ & $0.6 \pm 0.08 b$ \\
\hline (Auchenorrhyncha) & $5.6 \pm 0.95 \mathrm{a}$ & $2.0 \pm 0.25 b$ & $2.0 \pm 0.20 \mathrm{~b}$ \\
\hline (Sternorrhyncha) & $2.2 \pm 0.95 \mathrm{a}$ & $0.5 \pm 0.19 \mathrm{a}$ & $0.7 \pm 0.45 \mathrm{a}$ \\
\hline Hymenoptera & $0.8 \pm 0.19 \mathrm{a}$ & $0.4 \pm 0.10 \mathrm{a}$ & $0.5 \pm 0.09 \mathrm{a}$ \\
\hline Lepidoptera & $0.3 \pm 0.08 \mathrm{a}$ & $0.6 \pm 0.17 \mathrm{a}$ & $0.6 \pm 0.08 \mathrm{a}$ \\
\hline Orthoptera & $1.2 \pm 0.33 \mathrm{a}$ & $1.8 \pm 0.84 \mathrm{a}$ & $7.5 \pm 0.84 b$ \\
\hline Minor $^{\mathrm{a}}$ & $0.1 \pm 0.04 \mathrm{a}$ & $0.1 \pm 0.05 \mathrm{a}$ & $0.1 \pm 0.05 \mathrm{a}$ \\
\hline Non-insect $^{\mathrm{b}}$ & $0.2 \pm 0.07 \mathrm{a}$ & $0.1 \pm 0.08 \mathrm{a}$ & $0.4 \pm 0.07 \mathrm{a}$ \\
\hline All orders combined & $14.5 \pm 2.87 \mathrm{a}$ & $8.7 \pm 1.31 b$ & $14.2 \pm 1.15 \mathrm{a}$ \\
\hline
\end{tabular}

Means within the same row with the same letter are not different $(P>0.05)$ according to a Kruskal-Wallis test

${ }^{a}$ Minor insect orders included Neuroptera, Odonata, Pscoptera, and Thysanoptera

b Non-insect arthropod orders included Acari and Araneae

and vegetation structure. Such variation in botanical and structural diversity results in a patchy mosaic of microhabitats within grassland ecosystems, increasing the diversity and abundance of arthropod communities (Tscharntke and Greiler 1995; Dennis et al. 1998; Morris 2000; Jonas et al. 2002). Larger grassland areas, such as the JFKIA

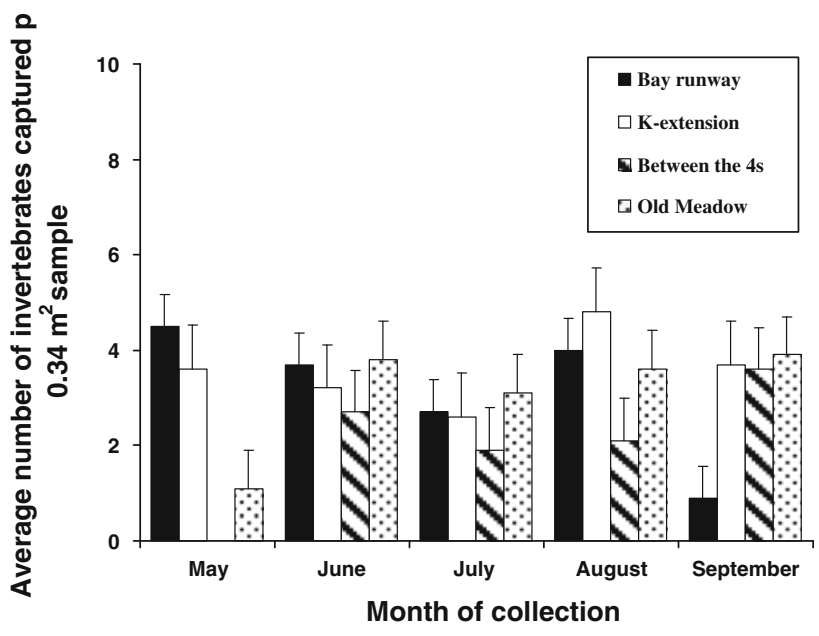

Fig. 3 Average number of arthropods per vacuum sample $\left(0.34 \mathrm{~m}^{2}\right)$ in four habitat areas of the airfield at John F. Kennedy International Airport, Jamaica, NY, May 2003 through September 2003. Error bars represent 1 standard error. Note: The Between the $4 \mathrm{~s}$ habitat area was not sampled in May of 2003

airfield, have the potential for more microhabitats than smaller habitat fragments (Bomar 2001).

Studies of arthropod communities in grasslands and agricultural systems suggest higher plant species richness and vegetation structural diversity (both vertical and horizontal) are correlated with increased insect diversity and abundance (Dennis et al. 1998; Wettstein and Schmid 1999; Jonas et al. 2002; Nemec and Bragg 2008). In this study, variation in plant communities and structure among the habitat areas on the JFKIA airfield influenced the 


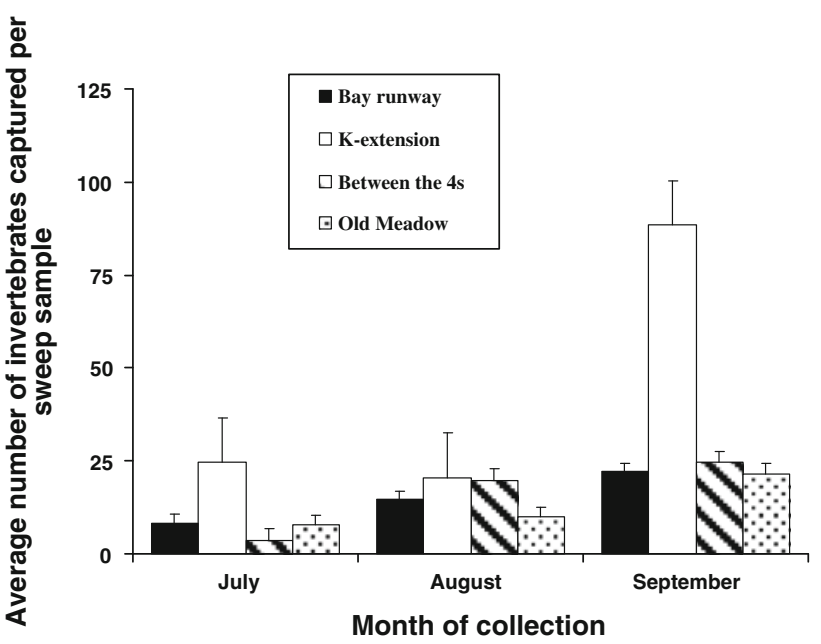

Fig. 4 Average number of arthropods per sweep-net sample in four habitat areas of the airfield at John F. Kennedy International Airport, Jamaica, NY, July 2003 through September 2003. Error bars represent 1 standard error

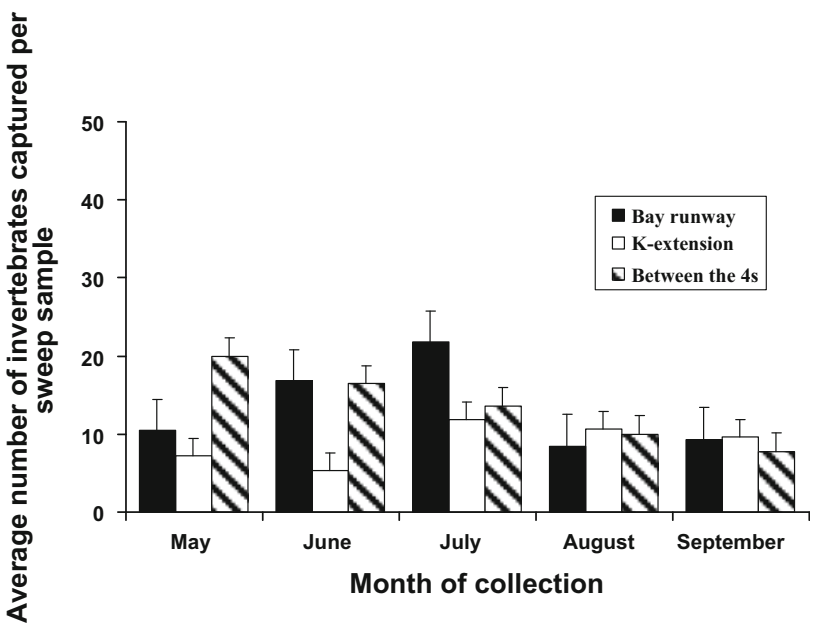

Fig. 5 Average number of arthropods per sweep-net sample in three habitat areas of the airfield at John F. Kennedy International Airport, Jamaica, NY, May 2004 through September 2004. Error bars represent 1 standard error

arthropod communities present in those habitat types. The higher abundance of forbs within the plant communities of the K-extension habitat area relative to the other habitat types could have provided a more diverse habitat structure (Söderström et al. 2001; Fuhlendorf et al. 2002; Nemec and Bragg 2008), resulting in the relatively high abundance of arthropods found in the 2003 sweep-net samples and high Hemipteran family diversity found in 2004.

The dominance of an exotic grass (B. japonica) within the Bay runway habitat area also provided vegetation with a high amount of vertical structure, a plant community characteristic associated with increased diversity and abundance of Auchenorrhyncha (Hollier et al. 1995; Dennis et al. 1998; Nickel and Hildebrandt 2003). Although there was a high abundance of Hemiptera in the Bay runway area, this area consistently had lower family richness of Hemipterans compared to other habitat areas.

As evidenced by high abundance of Orthoptera: Acrididae in 2004, the Between the 4s habitat area was most similar to a managed perennial turfgrass system and apparently provided microhabitats favorable to these insects (O'Neill et al. 2003; Marini et al. 2008). Similarly, the plant community and structure of this habitat area likely provided a variety of microhabitats utilized by Hemipterans, as this habitat area consistently had the highest levels of Hemipteran diversity.

Among the grassland habitat types on the airfield, the Old meadow habitat area was the most different, due to a higher amount of woody plant cover, relatively higher amounts of native plant species (e.g., native warm-season grasses), and overall less dense vegetation at the ground level. Such differences in vegetation structure and plant community composition likely influenced the composition of arthropod communities relative to the other habitat areas (Tscharntke and Greiler 1995; Wettstein and Schmid 1999; Jonas et al. 2002).

Methods of grassland management (e.g., mowing, livestock grazing) can have deleterious effects on invertebrate diversity and abundance, although the responses might not be the same for all arthropod groups (Tscharntke and Greiler 1995; Dennis et al. 1998; Morris 2000). Hemiptera communities, most notably Auchenorrhyncha, are more diverse and abundant in taller grassland habitats (i.e., those not mowed) compared to shorter swards (Hollier et al. 2005; Morris 2000; Nickel and Hildebrandt 2003). Jonas et al. (2002) found Orthopterans were sensitive to mechanical disturbance (i.e., haying) and were more abundant in non-disturbed grasslands. Marini et al. (2008) found intensive management of grasslands (e.g., more fertilizer applications and mowing several times per year) lowered Orthopteran diversity compared to grasslands managed with less intensity. Overall, Coleoptera appear to be less affected by mowing of grasslands than other arthropod orders (Dennis et al. 1998; Morris 2000); however, phytophagous beetle abundance or diversity might be reduced due to grassland management activities (i.e., mowing) that occur on airfields (Tscharntke and Greiler 1995).

Temporal patterns of arthropod abundance

Arthropod populations, especially Hemiptera and Orthoptera, are very dynamic and can exhibit considerable variation in diversity and abundance within and among years (Tscharntke and Greiler 1995; Hollier et al. 2005; Triplehorn and Johnson 2005; Nemec and Bragg 2008). Much of 
the temporal variation in arthropod abundance in the grassland habitats of the JFKIA airfield was related to changes in Auchenorrhyncha or Orthoptera: Acrididae populations. Auchenorrhyncha respond to changes in plant community characteristics, such as the reduction of vegetation height due to mowing activities (Morris 2000; Nickel and Hildebrandt 2003). Orthoptera species are particularly sensitive to climatic conditions (e.g., summer weather patterns) and microclimatic conditions related to plant community structure (O'Neill et al. 2003; Triplehorn and Johnson 2005; Marini et al. 2008).

\section{Differences between sampling methods}

A combination of arthropod sampling methods is required to effectively determine the structure and composition of terrestrial arthropod communities in grasslands due to varying effectiveness and biases associated with each sampling technique (MacLeod et al. 1994; Buffington and Redak 1998; Standen 2000). For this study, we used two standard sampling methods to characterize terrestrial arthropods within grasslands on the JFKIA airfield. Vacuum sampling captures both epiphytic (living on vegetation) and some epigeal arthropods, whereas the sweep-net sampling method primarily collects epiphytic arthropods from the upper portions of the vegetation swards (Hossain et al. 1999; Standen 2000; Morris 2000; Nickel and Hildebrant 2003).

The vacuum (or suction) sampling method has been used successfully to sample arthropod communities in grasslands (Törmälä 1982; Brook et al. 2008) and agricultural situations (MacLeod et al. 1994; Mommertz et al. 1996; Hossain et al. 1999). However, our findings suggest that using this technique in maritime grasslands characterized by sandy soils might be problematic. During vacuum sample collection, significant amounts of sand passed through the mesh and were collected as part of the arthropod sample. The movement of this material apparently caused substantial physical damage to some collected arthropods, and consequently their poor condition made identification difficult. Although some insect taxa (e.g., Coleoptera and Hymenoptera: Formicidae) are highly chitinous and might resist being fragmented in the vacuum sampling process, enough damage occurred to prevent family level identification of approximately $25 \%$ of the Coleoptera collected in the vacuum samples (compared to $10 \%$ of Coleoptera unidentified to family level in the sweep-net samples).

\section{Conservation value of airfield grasslands}

Our results suggest the JFKIA airfield represents a large, semi-natural grassland area that has the ability to support diverse and dynamic populations of terrestrial arthropods, although the airfield is isolated from other semi-natural grassland habitats by marine and urban environments. Given the airfield's proximity to Jamaica Bay (a marine ecosystem), the maritime semi-natural grassland plant communities of the airfield are likely influenced by salinity and other abiotic factors associated with coastlines (Morris 2000). The terrestrial environments surrounding the JFKIA are heavily urbanized areas consisting of large areas of impervious surfaces (e.g., pavement), thus the airfield likely serves as an isolated grassland habitat island with little potential for immigration or emigration of arthropods, in particular for species with limited mobility (Faeth and Kane 1978; Eversham et al. 1996; Tscharntke et al. 2002; Öckinger and Smith 2007).

With the potential exception of Floyd Bennett Field, located near JFKIA within the Gateway National Recreation Area, the JFKIA airfield is unique when compared to other urban grasslands within the metropolitan New York City area and western Long Island (Lent et al. 1997; Greller et al. 2000). All other grasslands habitats within this highly urbanized landscape are cool-season turfgrass areas found in residential and corporate lawns, urban parks, and golf courses. These areas are highly influenced by intensive management of vegetation and insect communities (e.g., intensive mowing, pesticides). Although community-level assessments and studies of arthropods within cool-season turfgrass areas (e.g., lawns, golf courses) within the northeastern United States are almost nonexistent (e.g., Rochefort et al. 2006), a review of available scientific studies about these turfgrass areas suggest lawns (Cockfield and Potter 1984; Potter and Braman 1991; Braman and Pendley 1993; Joseph and Braman 2009), golf courses (Braman et al. 2002; Yasuda and Koike 2006; Yasuda et al. 2008), and other turfgrass areas are dominated by insect pest species commonly identified as a problem within turfgrass areas (Cheng et al. 2008; Alumai et al. 2009). Future research is needed to determine the composition and diversity of arthropod communities within these urban grassland habitats in the northeastern United States and elsewhere.

Airports and military airfields represent a unique land use within urban and suburban landscapes. Airfield grasslands are managed (e.g., mowing, plant community renovation) for several reasons related to safe aircraft operations. In addition, airfield grasslands are often managed to reduce the numbers of insects (typically pest species in high abundance) that could attract birds and therefore increase the risk of bird-aircraft collisions (Caccamise et al. 1996; Bernhardt et al. 2010). Additionally, control programs might be implemented on airfields to prevent the spread of invasive insect species (e.g., Popilla japonica [Japanese beetles]; Hamilton et al. 2007). 
However, within the management paradigm for airfield grasslands there are clearly potential benefits for conservation of arthropods in suburban and urban areas. We suggest airports can provide important grassland habitats within highly urbanized landscapes for terrestrial arthropods, similar to other unique habitats (e.g., brownfield sites, green roofs).

The semi-natural and anthropogenically produced grassland habitats on the JFKIA airfield appear to have significant conservation value for arthropod communities within this urban environment. The mosaic of grassland habitats on the airfield provides a heterogeneous seminatural grassland environment, likely increasing biodiversity locally and within a larger urban ecosystem (i.e., the New York City metropolitan area) and potentially serves as a refugium for some terrestrial arthropod species (Faeth and Kane 1978; Panzer et al. 1995; McIntyre et al. 2001). Based on the findings from our community-level assessment, we suggest future research is needed to evaluate the value of these unique grassland habitat fragments, in particular for insect families and/or species groups of conservation interest (e.g., rare, threatened, or endangered species).

\section{Conclusions}

In summary, our study shows that arthropod populations in semi-natural grassland habitat fragments, such as those found on the JFKIA airfield, are abundant, diverse, and contain representatives from the major functional feeding groups. We found evidence of spatial and temporal variation of arthropod communities within these semi-natural urban grasslands, likely related to differences in plant community composition and vegetation structure among the habitat areas. These anthropogenically influenced grassland habitats are unique within this highly urbanized landscape which might serve as a refugium for grassland insects that require these habitats to persist. Consequently, such areas might have significant value for the conservation of terrestrial arthropods within urban areas. Future research is needed to further understand the role of seminatural grassland habitat fragments within highly urbanized environments have in preserving and enhancing invertebrate biodiversity. In addition, we suggest future efforts assessing the value of these habitat fragments to terrestrial insects of significant conversation concern are warranted.

Acknowledgments This research effort was funded by the Port Authority of New York and New Jersey and United States Department Agriculture-Animal and Plant Health Inspection Service-Wildlife Services. We thank various members of the USDA-APHISWildlife Services New York staff, especially D. Slater and A. Gosser, and the JFKIA Airfield Operations staff, especially S. Nowak, for their assistance in the field. In addition, we thank J. Dierker and S. Johnston for assistance with data entry. T. DeVault, T. Seamans, and 2 anonymous reviewers kindly provided helpful comments on earlier versions of this manuscript.

\section{References}

Alumai A, Sailminen SO, Richmond DS, Cardina J, Grewal PS (2009) Comparative evaluation of aesthetic, biological, and economic effectiveness of different lawn management programs. Urban Ecosyst 12:127-144

Askins RA (1997) History of grasslands in the Northeastern United States: implications for bird conservation. In: Vickery PD, Dunwiddie PW (eds) Grasslands of Northeastern North America. Massachusetts Audubon Society, Lincoln, pp 119-136

Barras SC, Dolbeer RB, Chipman RB, Bernhardt GE, Carrara MS (2000) Bird and small mammal use of mowed and unmowed vegetation at John F. Kennedy International Airport, 1998-1999, pp. 31-36. In Proceedings, 19th Vertebrate Pest Conference, March 6-9, 2000, University of California, Davis, CA

Bernhardt GE, Kutschbach-Brohl LA, Washburn BE, Chipman RB, Francoeur LF (2010) Consumption of terrestrial invertebrates by laughing gulls. Amer Midl Nat 163:442-454

Blair RB, Launer AE (1997) Butterfly diversity and human land use: species assemblages along an urban gradient. Biol Conserv $80: 113-125$

Bomar CR (2001) Comparison of grasshopper (Orthoptera: Acrididae) communities on remnant and reconstructed prairies in western Wisconsin. J Orthoptera Res 10:105-112

Borror DJ, White RE (1970) Peterson field guide: insects. Houghton Mifflin, New York

Braman SK, Pendley AF (1993) Relative and seasonal abundance of beneficial arthropods in centipedegrass as influenced by management practices. Hort Entomol 86:494-504

Braman SK, Pendley AF, Corley W (2002) Influence of commercially available wildflower mixes on beneficial arthropod abundance and predation in turfgrass. Environ Entomol 31:564-572

Brook AJ, Woodcock BA, Sinka M, Vanbergen AJ (2008) Experimental verification of suction sampler capture efficiency in grasslands of differing vegetation height and structure. J Appl Ecol 45:1357-1363

Buckley PA, McCarthy MG (1994) Insects, vegetation, and the control of laughing gulls (Larus atricilla) at Kennedy International Airport, New York City. J Appl Ecol 31:30-291

Buffington ML, Redak RA (1998) A comparison of vacuum sampling versus sweep-netting for arthropod biodiversity measurements in California coastal sage scrub. J Insect Conserv 2:99-106

Caccamise DF, Reed LM, DeLay LS, Bennett KA, Dosch JJ (1996) The avian communities of a suburban grassland refugium: population studies at an airport in Northeastern United States. Acta Ornithol 31:3-13

Cheng Z, Richmond DS, Salminen SO, Grewal PS (2008) Ecology of urban lawns under three common management programs. Urban Ecosyst 11:177-195

Clark TE, Samways MJ (1997) Sampling arthropod diversity for urban ecological landscaping in a species-rich southern hemisphere botanic garden. J Insect Conserv 1:221-234

Cockfield SD, Potter DA (1984) Predatory insects and spiders from suburban lawns in Lexington, Kentucky. Great Lakes Entomol 17:179-184

Collinge SK, Prudic KL, Oliver JC (2003) Effects of local habitat characteristics and landscape context on grassland butterfly diversity. Conserv Biol 17:178-187 
Dennis P, Young MR, Gordon IJ (1998) Distribution and abundance of small insects and arachnids in relation to structural heterogeneity of grazed, indigenous grasslands. Ecol Entomol 23:253264

Dillon ES, Dillon LS (1972) A manual of common beetles of Eastern North America, vol 1 and 2. Dover Publications, New York, NY

Dover JW, Dennis RLH, Atkins L (2009) The western jewel butterfly (Hypochrysops halyaetus: Lycaenidae) II: factors affecting oviposition within native Banksia bushland in an urban setting. J Insect Conserv 13:487-503

Eversham BC, Roy DB, Telfer MG (1996) Urban, industrial, and other man-made sites as analogues of natural habitats for Carabidae. Ann Zool Fenn 33:149-156

Eyre MD, Luff ML, Woodward JC (2003) Beeltes (Coleoptera) on brownfield sites in England: an important conservation resource? J Insect Conserv 7:223-231

Faeth SH, Kane TC (1978) Urban biogeography. City parks as islands for Diptera and Coleoptera. Oecologia (Berl.) 32:127-133

Frankie GW, Ehler LE (1978) Ecology of insects in urban environments. Annu Rev Entomo 23:367-387

Fuhlendorf SD, Engle DM, Arnold DC, Bidwell TG (2002) Influence of herbicide application on forb and arthropod communities in North American tallgrass prairies. Agric Ecosyst Environ 92:251-259

Gardiner T, Hill J (2006) A comparison of three sampling techniques used to estimate the population density and assemblage diversity of Orthoptera. J Orthoptera Res 15:45-51

Gaston KJ, Smith RM, Thompson K, Warren PH (2005) Urban domestic gardens (II): experimental tests of method for increasing biodiversity. Biodivers Conserv 14:395-413

Goldstein PZ (1997) History of grasslands in the Northeastern United States: implications for bird conservation. In: Vickery PD, Dunwiddie PW (eds) Grasslands of Northeastern North America. Massachusetts Audubon Society, Lincoln, pp 217-236

Gotelli NJ, Entsminger GL (2001) Quantifying biodiversity: procedures and pitfalls in the measurement and comparison of species richness. Ecol Letters 4:379-391

Gotelli NJ, Entsminger GL (2005) EcoSim: null models software for ecology. Version 7.72. http://garyentsminger.com/ecosim.htm. Accessed 5 Jan 2009

Greller AM, Durango C, Marchu LF, Wijesundara DSA, Byer MD, Cook RA, Tanacredi JT (2000) Phytosociological analysis of restored and managed grassland habitat within an urban national park. Urban Ecosyst 4:293-319

Hamilton RM, Foster RE, Gibb TG, Sadof CS, Holland JD, Engel BA (2007) Distribution and dynamics of Japanese beetles along the Indianapolis Airport perimeter and the influence of land use on trap catch. Environ Entomol 36:287-296

Harper CA, Guynn DC (1998) A terrestrial vacuum sampler for macroinvertebrates. Wildl Soc Bull 26:302-306

Hollier JA, Maczey N, Masters GJ, Mortimer SR (2005) Grassland leafhoppers (Hemiptera: Auchenorrhyncha) as indicators of habitat condition-a comparison of between-site and betweenyear differences in assemblage composition. J Insect Conserv 9:299-307

Hossain Z, Gurr GM, Wratten SD (1999) Capture efficiency of insect natural enemies from tall and short vegetation using vacuum sampling. Ann App Biol 135:463-476

Jonas JL, Whiles MR, Charlton RE (2002) Aboveground invertebrate responses to land management differences in a central Kansas grassland. Environ Entomo 31:1142-1152

Joseph SV, Braman SK (2009) Influence of plant parameters on occurrence and abundance of arthropods in residential turfgrass. J Econ Entomol 102:1116-1122

Kadas G (2006) Rare invertebrates colonizing green roofs in London. Urban Habitats 4:66-86
Kadlec T, Benes J, Jarosik V, Konvicka M (2008) Revisiting urban refuges: changes of butterfly and burnet fauna in Prague reserves over three decades. Landsc Urban Plann 85:1-11

Lent RE, Litwin TS, Cook RP, Bourque J, Bourque R, Tanacredi JT (1997) Grassland bird habitat restoration at Floyd Bennett Field, Brooklyn, New York: research and management. In: Vickery PD, Dunwiddie PW (eds) Grasslands of Northeastern North America. Massachusetts Audubon Society, Lincoln, pp 211-216

MacLeod A, Wratten SD, Harwood RWJ (1994) The efficiency of a new lightweight suction sampler for sampling aphids and their predators. Ann App Biol 124:11-17

Magurran AE (2004) Measuring biological diversity. Blackwell Science, Malden

Marini L, Fontana P, Scotton M, Klimek S (2008) Vascular plant and Orthoptera diversity in relation to grassland management and landscape composition in the European Alps. J Appl Ecol 45:361-370

McAlpine JF, Peterson BV, Shewel GE, Teskey HJ, Vockeroth JR, Wood DM (1981) Manual of Nearctic Diptera. vol. 1. Research Branch Agriculture Canada. Monogr. No. 27. Canadian Government Publication Centre, Hull

McAlpine JF, Peterson BV, Shewel GE, Teskey HJ, Vockeroth JR, Wood DM (1987) Manual of Nearctic Diptera. vol. 2. Research Branch Agriculture Canada. Monogr. No. 28. Canadian Government Publication Centre, Hull

McIntyre NF (2000) The ecology of urban arthropods: a review and a call to action. Ann Entomol Soc Am 93:825-835

McIntyre NE, Thompson TR (2003) A comparison of conservation reserve program habitat plantings with respect to arthropod prey for grassland birds. Am Mid Nat 150:291-300

McIntyre NE, Rango J, Fagan WF, Faeth SH (2001) Ground arthropod community structure in a heterogeneous urban environment. Landsc Urban Plann 52:257-274

Mehrhoff LJ (1997) Thoughts on the biogeography of grassland plants in New England. In: Vickery PD, Dunwiddie PW (eds) Grasslands of Northeastern North America. Massachusetts Audubon Society, Lincoln, pp 15-23

Mommertz S, Schauer C, Kosters N, Land A, Filser J (1996) A comparison of D-vac suction, fenced and unfenced pitfall trap sampling of epigeal arthropods in agro-ecosystems. Ann Zool Fenn 33:117-124

Morris MG (2000) The effects of structure and its dynamics on the ecology and conservation of arthropods in British grasslands. Biol Conserv 95:129-142

Nemec KT, Bragg TB (2008) Plant-feeding Hemiptera and Orthoptera communities in Native and restored mesic tallgrass prairies. Restor Ecol 16:324-335

New TR (2005) Recreation and reserves: values of golf courses for insect conservation. J Insect Conserv 9:1-2

New York City Department of Environmental Protection [NYCDEP] (2007) Jamaica Bay watershed protection plan. http://home2.nyc. gov/html/dep/html/dep/html/dep_projects/jamaica_bay.shtml. Accessed 15 Nov 2008

Nickel H, Hildebrandt PA (2003) Auchenorrhyncha communities as indicators of disturbance in grasslands (Insecta, Hemiptera) - a case study from the Elbe flood plains (northern Germany). Agric Ecosyst Environ 98:183-199

Norment CJ (2002) On grassland bird conservation in the northeast. Auk 119:271-279

O'Neill KM, Olson BE, Rolston MG, Wallander R, Larson DP, Siebert CE (2003) Effects of livestock grazing on rangeland grasshopper (Orthoptera: Acrididae) abundance. Agric Ecosyst Environ 97:51-64

Öckinger E, Smith HG (2007) Semi-natural grasslands as population sources for pollinating insects in agricultural landscapes. J Appl Ecol 44:50-59 
Panzer R, Stillwaugh D, Gnaedinger R, Derkovitz G (1995) Prevalence of remnant dependence among prairie- and savanna-inhabiting insects of the Chicago region. Nat Areas $\mathbf{J}$ 15:101-116

Picker MD, Samways MJ (1996) Faunal diversity and endemicity of the Cape Peninsula, South Africa-a first assessment. Biodivers Conserv 5:591-606

Potter DA, Braman SK (1991) Ecology and management of turfgrass insects. Annu Rev Entomol 36:383-406

Pöyry J, Paukkunen J, Heliola J (2009) Relative contributions of local and regional factors to species richness and total density of butterflies and moths in semi-natural grasslands. Comm Ecol 160:577-587

Pyle R, Benzie M, Opler P (1981) Insect conservation. Annu Rev Entomol 26:233-258

Rochefort S, Shetlar DJ, Brodeur J (2006) Ground beetle assemblages (Coleoptera: Carabidae) and their season abundance in cool season turfgrass lawns of Quebec. Environ Entomol 35:1508-1514

Schrader S, Böning M (2006) Soil formation on green roofs and its contribution to urban biodiversity with emphasis on Collembolans. Pedobiologia 50:347-356

Smith RM, Gaston KJ, Warren PH, Thompson K (2006) Urban domestic gardens (VIII): environmental correlates of invertebrate abundance. Biodivers Conserv 15:2515-2545

Söderström B, Svensson B, Vessby K, Glimskär A (2001) Plants, insects, and birds in semi-natural pastures in relation to local habitat and landscape factors. Biodivers Conserv 10:1829-1863

Standen V (2000) The adequacy of collecting techniques for estimating species richness of grassland invertebrates. J Appl Ecol 37:884-893

Stewart AJA, Wright AF (1995) A new inexpensive suction apparatus for sampling arthropods in grassland. Ecol Entomol 20:98-102

Törmälä T (1982) Evaluation of five methods of sampling field layer arthropods, particularly the leafhopper community, in grassland. Ann Entomol Fenn 48:1-16
Triplehorn CA, Johnson N (2005) Borror and Delong's introduction to the study of insects, 7 th edn. Brooks Cole, Belmont

Tscharntke T, Greiler HJ (1995) Insect communities, grasses, and grasslands. Ann Rev Entomol 40:535-558

Tscharntke T, Steffan-Dewenter I, Kruess A, Thies C (2002) Contribution of small habitat fragments to conservation of insect communities of grassland-cropland landscapes. Ecol Appl $12: 354-363$

United States Department of Agriculture [USDA] (2005) New York City Reconnaissance soil survey. United States Department of Agriculture, Natural Resources Conservation Service, Staten Island

United States Fish and Wildlife Service [USFWS] (1997) Significant habitats and habitat complexes of the New York Bight Watershed (http://training.fws.gov/library/pubs5/begin.html)

Valtonen A, Saarinen K, Jantunen J (2007) Intersection reservations as habitats for meadow butterflies and diurnal moths: guidelines for planning and management. Landsc Urban Plann 79:201-209

Wettstein W, Schmid B (1999) Conservation of arthropod diversity in montane wetlands: effects of altitude, habitat quality, and habitat fragmentation on butterflies and grasshoppers. J Appl Ecol 36:363-373

Yasuda M, Koike F (2006) Do golf courses provide a refuge for flora and fauna in Japanese urban landscapes? Landsc Urban Plann 75:58-68

Yasuda M, Koike F, Terman M (2008) How management practices affect arthropod communities on Japanese golf courses? Landsc Ecol Eng 4:133-138

Zapparoli M (1997) Urban development and insect biodiversity of the Rome area, Italy. Landsc Urban Plann 38:77-86

Zar JH (1996) Biostatistical analysis, 3rd edn. Prentice Hall, Upper Saddle River 